\title{
Analysis of the water, energy, and food nexus using system archetypes: A case study in the Jatiluhur reservoir, West Java, Indonesia
}

\author{
Author: Bahri, Muhamad ${ }^{1}$
}

\begin{abstract}
The reservoir usually has multiple functions such as hydropower and water distribution for different end users. Multiple functions and multiple agents also mean there are tradeoffs among multiple functions among different end users. Through feedback loops, the system dynamics tools concern on the interdependency and the complexity of the nexus elements. This paper applies the system archetypes in investigating water-energy-food-land nexus (WEFLN) in the Jatiluhur reservoir, the largest reservoir in Indonesia. Using the system archetypes. It is found that there are growth engines to support industrial, residential, and fisheries sectors. However, water availability will be a crucial issue that possibly bounds the growth engines. This situation is called the limits to growth archetype. Another system archetype, the success to successful, is also identified. This archetype reminds us the distribution of water and power should be adjusted accordingly to sustain the growth in all sectors including industry, residence, and

fisheries.
\end{abstract}

Keywords: nexus; water; food; energy; system archetypes; system dynamics

${ }^{1}$ Victoria University of Wellington, Wellington School of Business and Government, 33 Bunny Street, Pipitea, Wellington 6011, New Zealand

Email: mkhairulbahri@ymail.com

\section{Introduction}

The reservoir can provide multiple benefits for human being. For instance, the Guadalest and Amadorio reservoirs in the Spanish Mediterranean not only distribute water for households but also provide water to secure crop production in the Marina Baixa County, Spain (e.g. Castaño et al., 2001). Another instance is the reservoir in Zayandeh-Rud river basin, Iran provides water for industry, households, and farmers (e.g. Gohari et al., 2014).

The reservoir system is a complex system consisting a dynamic interaction between living and non-living things (e.g. Gohari et al., 2014; Madani, \& Mariño, 2009). Living things are, for example, human beings and crops and non-living thing are climate, water, and pellets (food for fish). The interaction can be too complex as human intervention may significantly influence the reservoir system. Because of its complexity, there are lot of studies explore the dynamic interaction in the reservoir system. 
Despite its complexity, the reservoirs are useful for human beings (Bahri et al., 2018; Castaño et al., 2001; Rico-Amoros et al., 2013; Martínez-Ibarra, 2015). The reservoir can provide water source for irrigation, industry, and household (e.g. Astuti, 2016; Bahri et al., 2018; Castaño et al., 2001; Hardjamulja et al., 1988). The reservoirs also provide us electricity through hydropower and food through fish production and crop production.

Some studies (Gohari et al., 2014; Madani, \& Mariño, 2009) investigated the reservoir in Iran and found that there are dynamic and complex relationships among agents surrounding the reservoir. They also found multiple agents compete water for multi purposes such as household, farmers, and industry. They, furthermore, argue that system dynamics tools including stock-flow model and a causal loop diagram are suitable tool to analyze the complex system like the reservoir.

Other studies (Chippi-Shresta et al., 2017 ; Sohofi et al., 2016) are a step ahead by stating that the complex system where multiple agents compete for a limited resource such as water should be analyzed as a nexus study. This does not mean, however, that earlier studies did not aware of the nexus concept. Rather earlier studies such as Mirchi, \& Watkins (2012), Gohari et al. (2014), and Madani and Mariño (2009) did not explicitly state the nexus concept in their studies. In principle, those earlier studies explained a water and food nexus as those studies analyzed water consumption for population, industry, and agriculture.

All of these points should be evidence to discuss the dynamic of the reservoir system as a nexus study. Moreover, the nexus concept is useful as multiple agents compete for limited resources such as water, energy, and food. The nexus aims to balance the resource among agents proportionally in achieving sustainable development or sustainable goals.

Despite aforementioned studies, there are limited studies in applying the nexus concept in Indonesian case studies. In turn, this study aims to explain dependency between water, energy, and land in the county as well as to look at a sustainable solution in sustaining the WEFLN. This study discusses the Jatiluhur reservoir, the largest reservoir in Indonesia. The reservoir is a multi-purpose reservoir for irrigation, household, and industry. Nexus elements in the reservoir are energy (hydropower), water (irrigation and urban areas), and food (rice production).

Moreover, this study starts with preliminary studies in the water management and the application of system archetypes. Afterward, a short description of the case study and an applied method or system archetypes are explained. Outputs of this study and relevant discussion are described are explained in the next step. At the end, relevant conclusions are summarized to remind readers about results and important points taken from this study.

\section{Materials and methods}

\subsection{The case study}

The Jatiluhur reservoir, located in Purwakarta, West Java, is the largest and probably the most important dam in Indonesia (Hamzah, 2017). The reservoir also relatively close to Jakarta, the capital city of Indonesia. The climate condition highly supports the reservoir as annual rainfall is about $3,000 \mathrm{~mm} /$ year. This annual rainfall falls about 70 percent of total 
rainfall during the rainy seasons and 30 percent in the dry seasons (BPS Jabar, 2018). Relative humidity is 80 percent and average daily temperature is $25^{\circ} \mathrm{C}$ in terrain and $18^{\circ} \mathrm{C}$ in the mountains (BPS Jabar, 2018).

The catchment area is about 8,000 hectares and 2.4 billion meters cubic of water (Koeshendrajana et al., 2011). This dam was built in 1957 to firstly support farming areas surrounding the dam. The Jatiluhur reservoir serves as an irrigation water supply for 242,000 hectares of rice fields, a main source of drinking water, and the flood control (Hamzah, 2017).

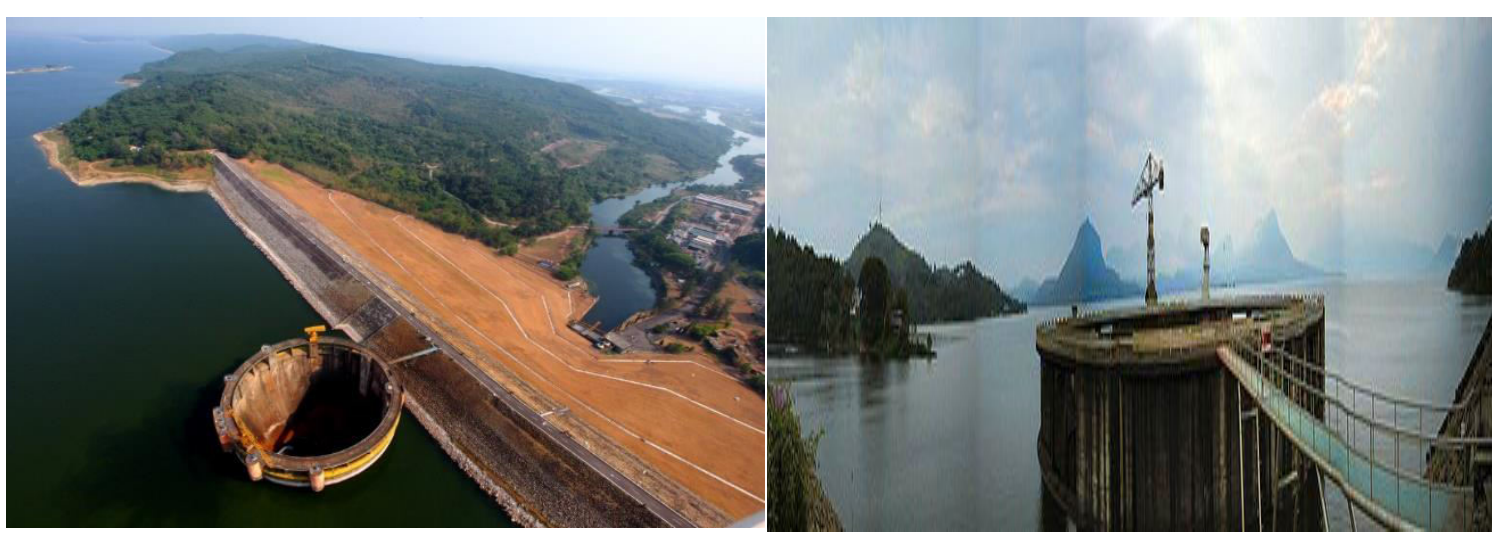

(a)

(b)

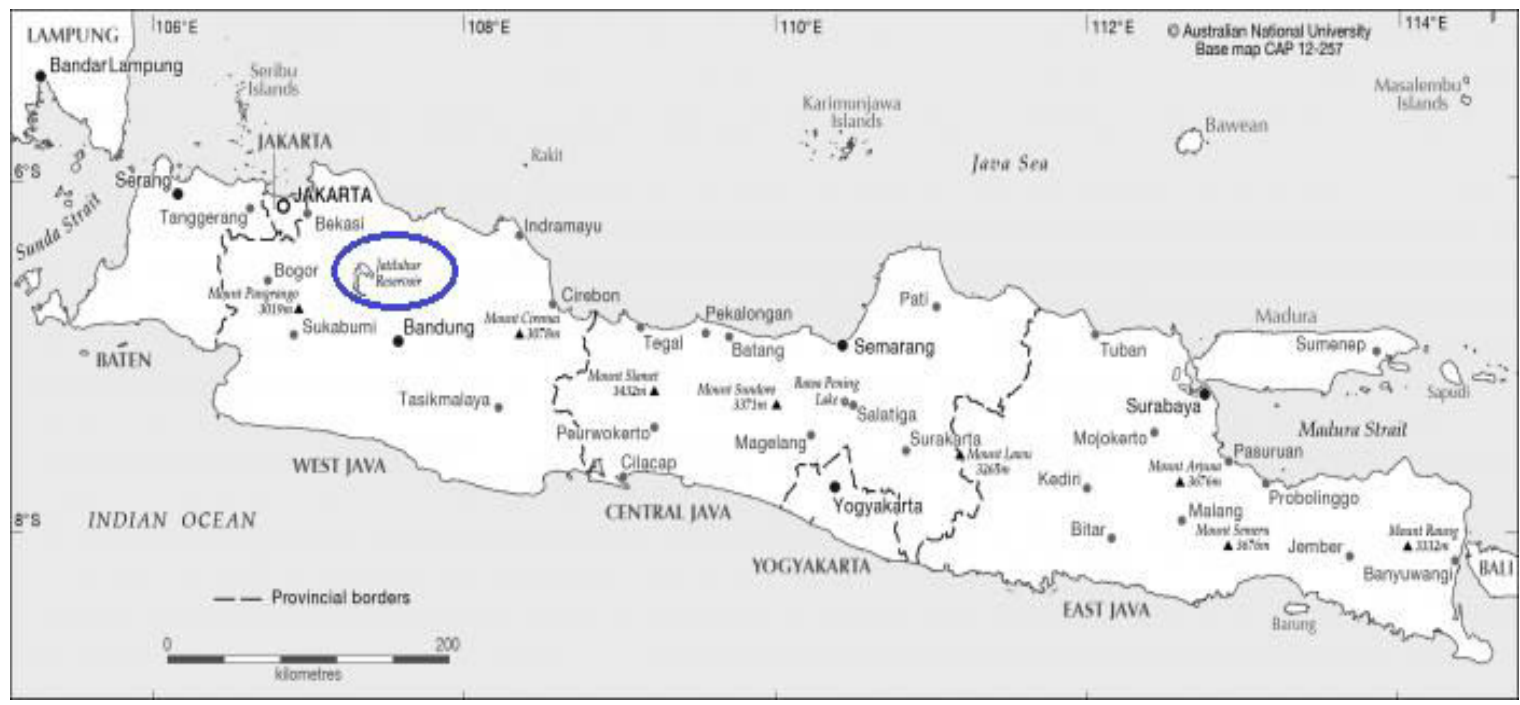

(c)

Figure 1. The Jatiluhur reservoir from the sky (a), from a short distance (b), and in the map (source: http://citarum.org/tentang-kami/sekilas-citarum/kondisi-fisik-dan-spasial.html)

The Jatiluhur reservoir is about $90 \mathrm{kms}$ from Jakarta and Bekasi (a main satellite of Jakarta). The Jatiluhur reservoir is also purposeful to provide water for household and industries in Jakarta and Bekasi (Samekto \& Winata, 2010). Owing to land conversion (to increase industrial areas and for housing), water demand tends to increase. Conversion land 
agriculture for other purposes such as urban areas and industrial purposes leads an increase in water demand for municipal and industry (Kurnia et al., 2000).

This reservoir is also equipped by six units of $187 \mathrm{MwH}$ turbines, generating power/electricity about 1000 million kilo-Watt-hour (kWh) each year (Hamzah, 2017). So, the reservoir is the largest hydropower system and the largest runoff system in Indonesia. Because the Jatiluhur reservoir is the largest Indonesian reservoir, the reservoir has attracted local and international tourists. Owing to this, the reservoir surrounding areas are equipped with leisure facilities such as lodging, restaurants, tennis courts as well as sports facilities and water recreation such as rowing, and windsurfing (Pratiwi, 2010). Again, owing to its large water volume, some people do fishing regularly.

The management of water distribution in the Jatiluhur reservoir is a critical issue owing to high population growth, increase in food demand, urban expansion and industry growth over time. It seems that an increase water demand owing to population growth and industrial growth has increased a challenge in distributing water for irrigation, domestic and industrial water purposes (ADB, 2012; Kartamihardja, \& Umar, 2006; Hasan, 2011; Slametto, 2012).

\subsection{Research approach}

To identify the system archetypes, a combination of data, interviews, and literature review was applied in this study. Relevant literature review and information from relevant stakeholders were collected. Other data through available online and literature review were also collected. This is possible as existing studies about the reservoir are available online such as in http://repository.ipb.ac.id. These data are including the number of fish cages, water level, and power production.

The reservoir management is so complex, so data about the water management and its policy were collected through interviews and workshops, involving some stakeholders (Fitri, 2016; Hasan, 2011; Karunia, \& Marinasari, 2015). Based on this collected information, nominated system archetypes are nominated and then the best system archetypes are chosen (Braun, 2002). In principle, all of these, data, storylines and literature, enable the author to generate a new concept of development: system archetypes (Senge, 2014; Wolstenholme, 2004).

In addition to the development of system archetypes, there are four levels of system thinking which show steps by steps the thinking should explore the real world. These four level are events, patterns, systemic and mental model levels as seen in figure 2 . The most visible level is events, which mean that decision makers easily can see problems or address issues at the events level. 


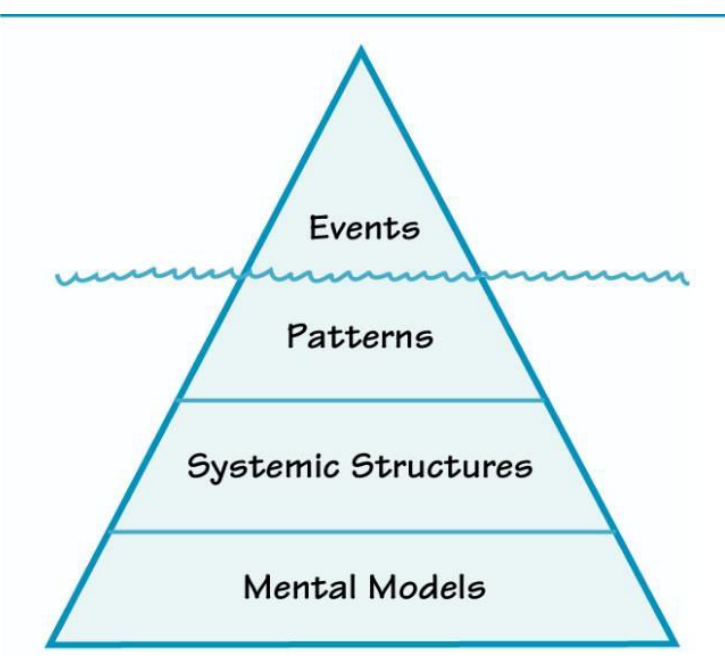

Figure 2. Four levels of system thinking (source: https://thesystemsthinker.com/systemsmethodology/).

Because of this, decision makers usually solve or offer solutions based on the events they see. Solutions derived from events level usually only cure the symptoms not the causes, leaving unsolved issues of the observed systems.

In the Jatiluhur reservoir, as seen in the section the case study, is the main source of water for the capital city of Jakarta, water for irrigation areas in West Java (the third largest rice producer in Indonesia), power for Java and Bali island, and the fisheries sector. Owing to its importance, there are international (e.g. ADB, 2012) and national efforts (e.g. Kartamihardja, \& Umar, 2006) to address issues at events level which have addressed symptoms instead of causes.

The second level is patterns or can be called patterns of behavior. Patterns of behavior can be detected through behavior over time (BOT) of systems (Senge, 2006). This shows how observed systems act or change over time. Compared with events level, this level provides more meaningful information. In the case study, the Jatiluhur reservoir shows an increase in water demand, power demand, and fish production.

It is interesting to reveal that the reservoir has experienced increases in important variables such as water supply, and power supply. However, there is a concern that environmental degradation may happen in the reservoir. As seen in figure 3, environmental degradation issues occur as sedimentation, corrosive water turbines, and massive eutrophication.

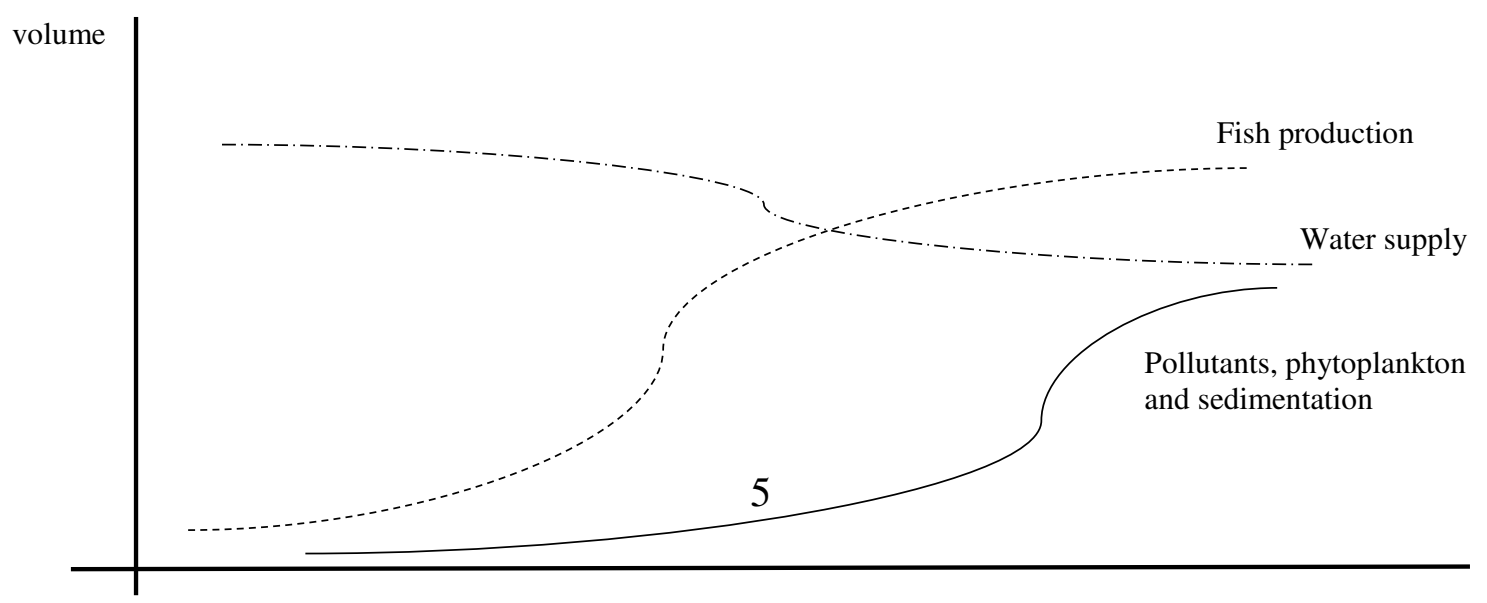




\section{(Time)}

Figure 3. Behavior over time in the reservoir

The third level of the system thinking is systemic structures that connect multiple agents in the observed system. In this level, it can be seen interactions among agents and how they affect each together. In this level, a causal loop diagram (CLD) is a tool displaying causalities among actors (Maani \& Cavana, 2007; Ford, 1999; Sterman, 2000). The CLD was developed through involvement of relevant stakeholders through workshops. The CLD was also supported by relevant literature and available document from multiple sources. Figure 4 shows the CLD of multiple agents in the Jatiluhur reservoir. 


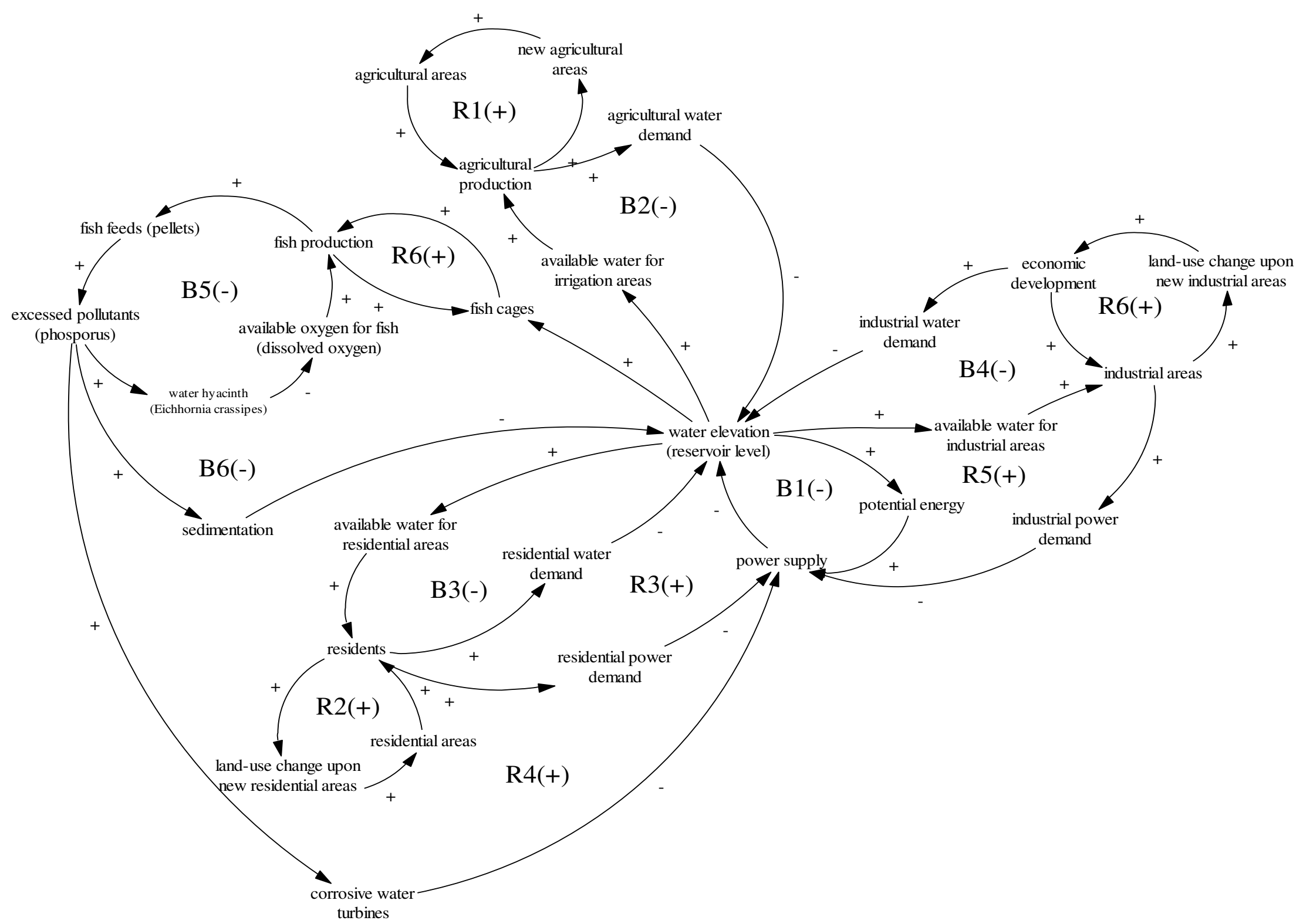

Figure 3. A causal loop diagram - water, energy, food, and land nexus in the Jatiluhur reservoir 
Nexus means a link or a connection of dependent elements. In principle, it is impossible to discuss one element only since each element in the nexus is dynamically dependent to other elements (e.g. Giampietro et al., 2014). As seen in the CLD, the connection between nexus elements are visible. Water is required to support irrigation areas, and fish production. The link between water and irrigation areas as well as fish production means water and food cannot be separated. Furthermore, water can affect industrial and residential land, confirming a link between land and water.

Water is also required to generate power for end users. A higher water volume leads to a higher power availability, which means that more water for irrigation areas leads to less power availability and vice versa. This means there is an indirect link between power and food (irrigation areas). Another indirect link is between land and food, when more water goes to irrigation areas, less water will be available to support industrial and residential areas.

In addition to the system thinking, the mental level is the fourth level. Through the mental level, we can see observed systems based on our beliefs, values, and assumptions, which lead to the way we do or act (Maani \& Cavana, 2007). Based on workshops and interview, it is widely accepted that the need for the integrated planning is important to achieve sustainable functions in the Jatilluhur reservoir. It is also found that uncontrolled fisheries activities can lead a terrible environmental degradation. Relevant stakeholders also remind us to increase our concern on integrated efficiencies in the operating of the multiple function reservoir.

Aforementioned statements are a sample of different mental models that are inherent in the system development. Moreover, existing studies (Deswati, \& Adrison, 2019; Karunia, \& Marinasari, 2015; Fitri, 2016) show that local agents have little knowledge on sustainability and the importance of sustainability to sustain the reservoir uses for all in achieving sustainable fish production, sustainable power generation, and sustainable irrigation areas.

\subsection{System archetypes}

The system archetypes are a qualitative system dynamics tool consisting some feedback loops. They are firstly coined by Senge (1990) who also recorded several frequent systemic structures and their behavior patterns. Up to date, there are more about ten types of system archetypes such as Limits to growth, Shifting the Burden, and Success to Successful (Kim, 1992; Braun, 2002). Those studies (Kim, 1992; Braun, 2002) suggest identifying system archetypes through storylines and literature review, especially if data is limited. Those studies (Kim, 1992; Braun, 2002) also explain that system archetypes are a combination of two or more feedback loops either a reinforcing loop or a balancing loop.

A feedback loop is a combination two or causal links between elements that are connected in such a way, one eventually returns to the first element. For example, if a change in variable A directly causes a change in variable $B$ which directly causes a change in variable $\mathrm{C}$, which in turn

directly causes a change of our initial variable A, then we are dealing with a feedback loop. 
There are types of loops, a reinforcing loop and a balancing loop. A reinforcing loop means a self-reinforcing activity while a balancing loop means a self-correcting activity as seen in figure 5 .
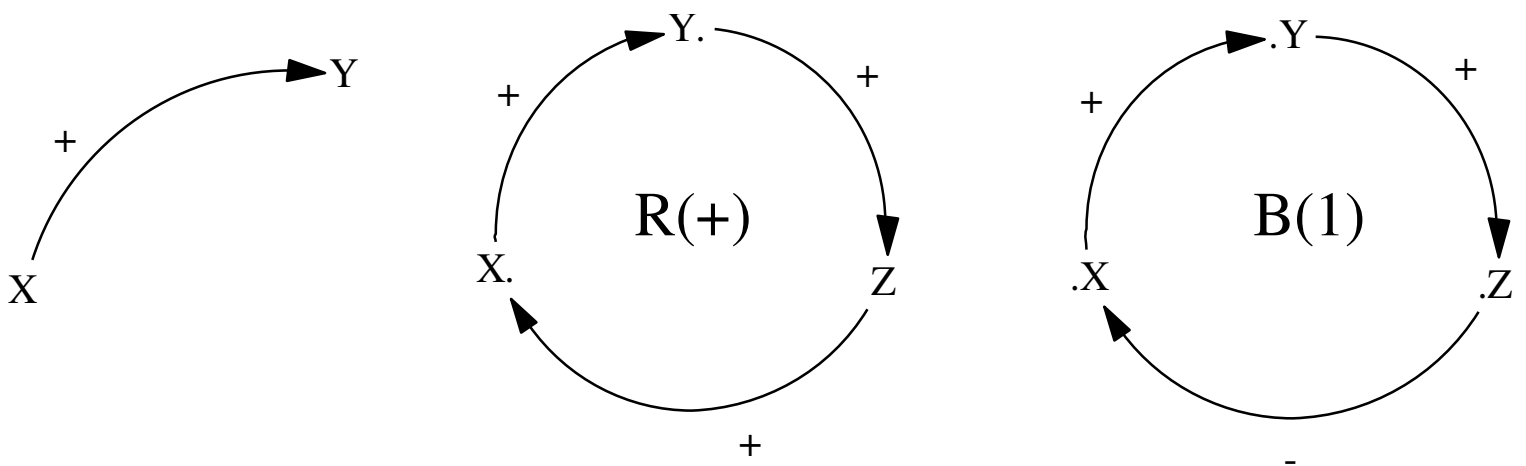

Figure 5. A causal link and feedback loops. Reinforcing loop (R+) \& Balancing loop (B-)

A real example of the feedback loop is displayed in figure 6. The Jatiluhur reservoir operates six water turbines to generate power for Java and Bali. Power generation is based on the potential energy in which a higher elevation leads to a higher power or electricity. As reservoir level increases, elevations of the reservoir also increases. This relationship is an in-line relationship where two variables moves in the same direction (reservoir level increases leads to a higher water elevation), so a sign "+" is put between "reservoir level" and "water elevation". A "+" sign is also put between "water elevation" and "potential energy" and between "potential energy" and "power supply". A "-" sign dealt with a relationship in which both variables do not move in the same direction. For instance, more "power supply" leads to less "water elevation". The latter means as "power supply" increases, "water elevation" decreases.

A loop is a situation when a relationship leads to a circle. A balancing loop (B1) is a result a circle relationship among water elevation, potential energy, and power supply. A balancing loop means that a circle relationship or a closed relationship leads to a goal. For B1, this means that the system seeks stability to generate power supply based on given available water.

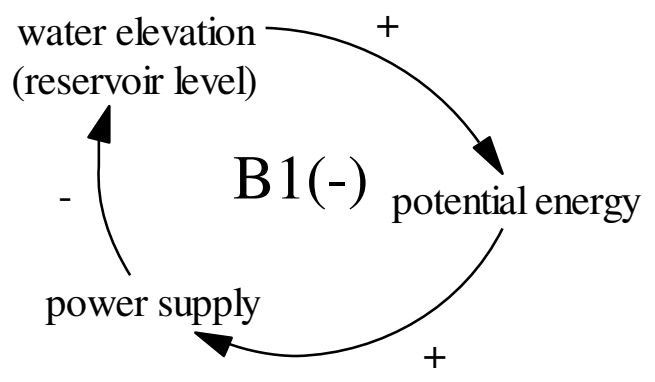

Figure 6. A balancing loop (power supply) 
There are lot existing studies that use the system archetypes to explain some insights in different fields. Again, the system archetypes are used to find insights and perspectives in the organic food system in Europe (Brzezina et al., 2017), the agriculture system (Banson et al., 2016; Nguyen, \& Bosch, 2013) and the nexus (Sohofi et al., 2016). However, none of the existing studies investigates the system archetypes in water-energy-food nexus.

\section{Results and discussion 3.1 Agriculture}

An important loop in the irrigation side is a reinforcing loop where a closed relationship leads to the growth shape. A reinforcing loop (R1) means that "new agricultural areas" leads to a higher "agricultural production" and as "agricultural production" attracts farmers to open "new agricultural areas". The reinforcing loops is called the growth engine.

Figure 7 reproduces a system archetype, so called the limits to growth. The limits to growth occurs when the growth is bounded by a limited resource. In this situation, an increase in agricultural production is limited by available water for irrigation areas. Although a reinforcing loop (R1) supports a continuous growth of agricultural production, it is limited by water availability (B1).

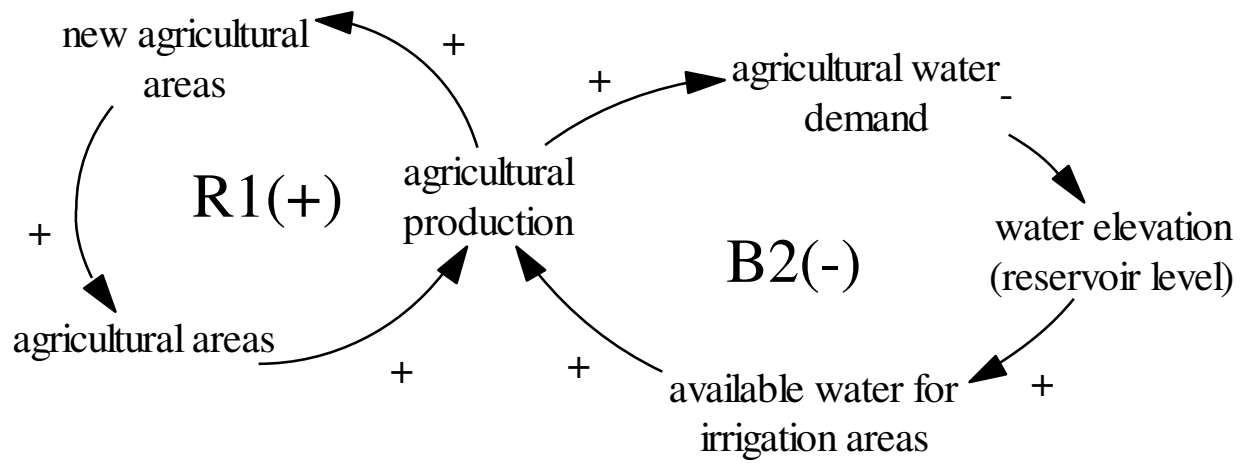

Figure 7. The limits to growth \#1

Possible solutions to overcome the bottleneck in the limits to growth is to remove barriers (Senge, 1991, Maani \& Cavana, 2007). For instance, farmers may apply the drip irrigation so there are more farming areas for the same amount of water. An increase in water supply such as additional inflows from other surces is also another possible solution.

\subsection{Fisheries}

There are two types fisheries activities in the reservoir: the cultivated fishing and uncultivated fishing. The uncultivated fishing is not endangering fish species and fish production 
as fish farmers use sustainable fishing methods to catch fish while the cultivated fishing has been warned as an unsustainable fishing. In the Jariluhur reservoir, the most important cultivated fishing is fish cages. While the uncultivated fishing was firstly practiced in the mid-1960s, fish cages was firstly introduced time in 1988 (Astuti et al., 2016). Since that time, fisheries production has increased rapidly, from about 2,000 tonnes in 1994 to about 20,000 tonnes by 2000s (Astuti et al., 2016). The fisheries sector of the Jatiluhur contributed to fish production, employment, and income for people who live in surrounding areas of the reservoir (e.g. Astuti et al., 2016).

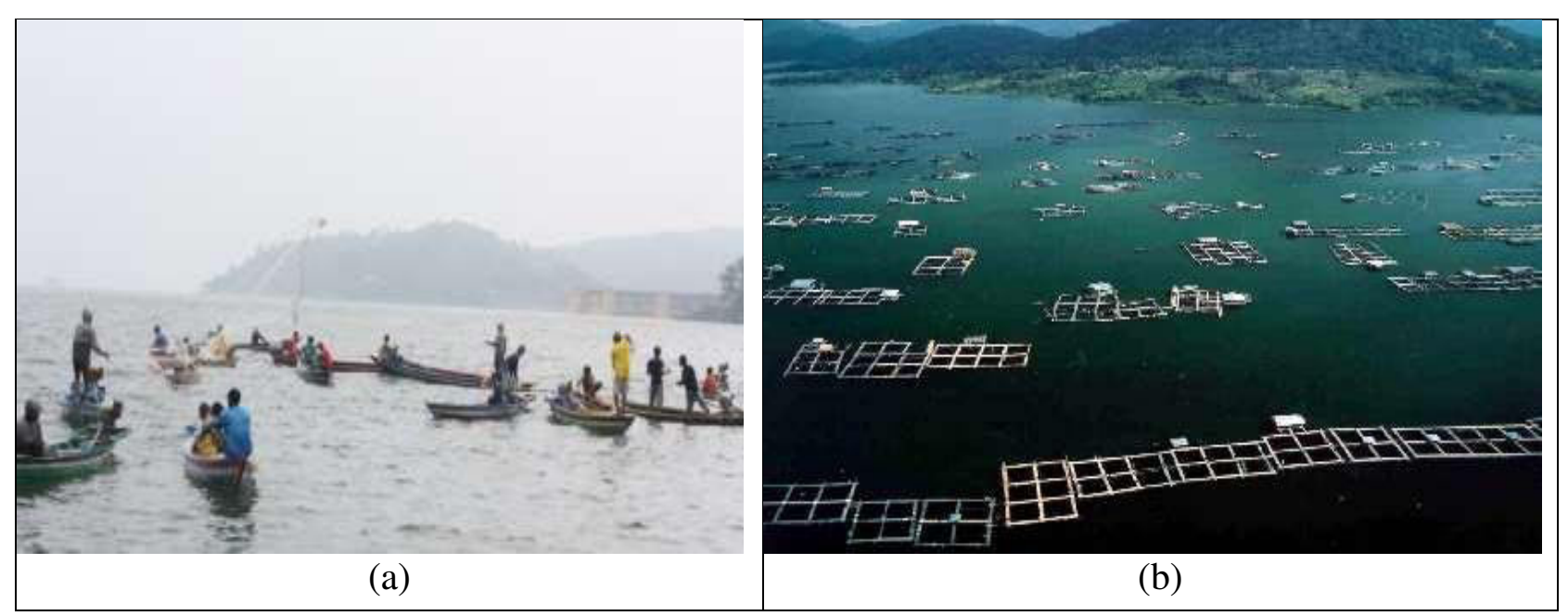

Figure 8. Uncultivated fishing (a) and cultivated fishing or fish cages (b)

At early stage, the number of fish cages increased significantly by $25 \%$ by 2000 s as seen in figure 9. The fish production upon the fish cages also increased significantly from 7,000 tonnes to 15,000 tonnes during 2000s (Astuti et al., 2016). Successful fish cages and a significant increase in the fish production attracted more farmers to invest their money in fish cages. This is called a reinforcing loop as seen in figure 10. A reinforcing loop (R6) explains that more fish production leads to more fish cages and vice versa, leading to the growth of fish production through fish cages. 


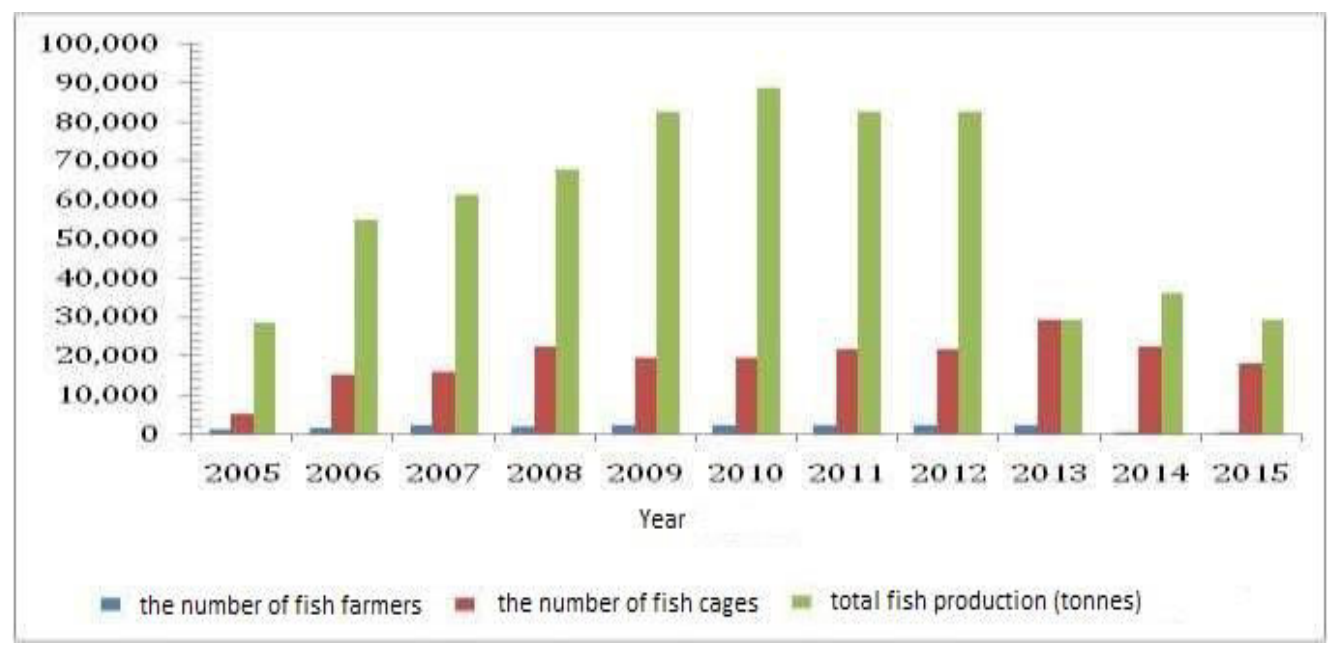

Figure 9. The number of fish cages and the fish production

Despite its importance and benefit, the cultivated fishing i.e. fish cages induced some negative externalities. As seen in figure 10, more fish feeds lead to excessed pollutants that lie in the bottom of the reservoir ( a "+" sign between fish feeds and excessed pollutants). Increased pollutants lead to water hyacinth (latin: eichhornia crassipes) and then decreased dissolved oxygen for fish. In general, water hyacinth provides many benefits such as places of fish eggs and increased food for fish. However, excessed pollutants tend to push the growth of water hyacinth exponentially - so called eutrophication, leading to less dissolved oxygen (e.g. Astuti et al., 2016; Pratiwi, 2009).

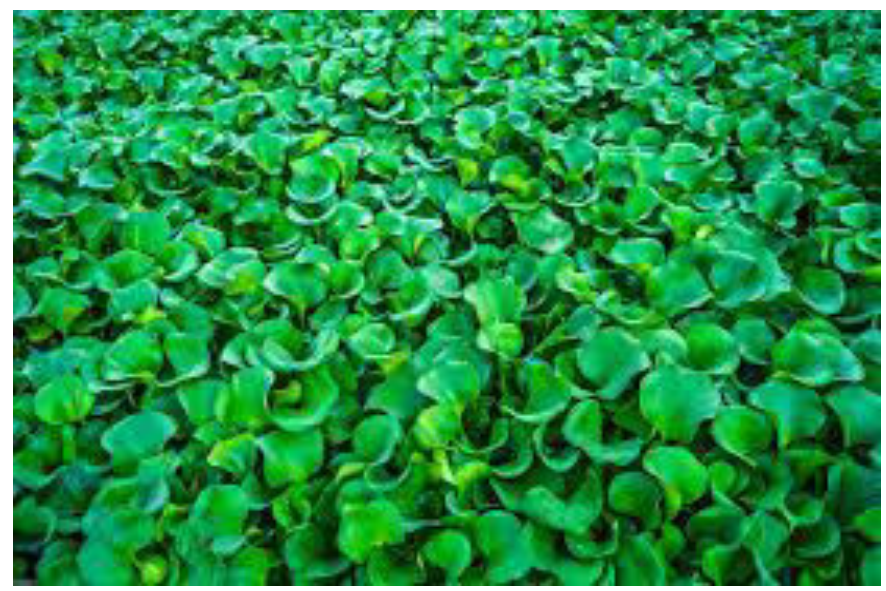

Figure 10. Water hyacinth (Eichhornia crassipes)

That study (Astuti et al., 2016; Pratiwi, 2009) also explains that concentrations of dissolved oxygen tend to decrease from $5.4 \mathrm{mg} / \mathrm{litres}$ in 1977 to $0.4 \mathrm{mg} / \mathrm{litres}$ in 2015 . The main cause of decreased dissolved oxygen is the high concentration pollutants upon the application fish cages (Astuti et al., 2016; Pratiwi, 2009). Excessed pollutants also, as seen in figure 11, also leads to 
sedimentation, reducing the reservoir's water level (Kajisa, \& Dhalhar, 1998; Santana Aji, 2014). Figure 11 also explains that excessed pollutants led to corrosive water turbines that in turn, negatively influence power supply (Astuti et al., 2016).

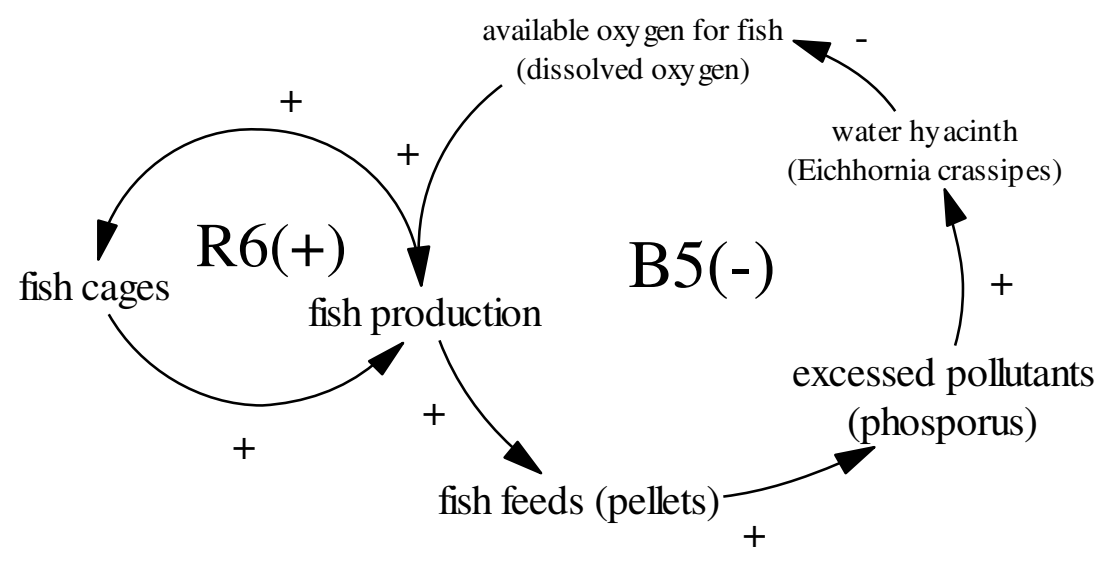

Figure 11. The limits to growth \#2

Figure 12 tells us that a reinforcing loop (R6: fish production - fish feeds - fish production) is negatively influenced by two balancing loops (B5, and B6). These two balancing loops (B5 and B6) remind us that excessive fish cages lead to less fish production and sedimentation respectively. Owing to this, there were a lot of warnings from some stakeholders such as scientists and local councils about the negative effects of fish cages, especially after the number of fish cages were overcapacity, compared with the reservoir capacity. However, fisheries businesses neglected this warning. As a consequence, B6 (fish feeds - excessed pollutants water hyacinth - available oxygen for fish - fish production - fish feeds) led to massive dead fishes about 2,000 tonnes, 900 tonnes, and 2,000 tonnes in 1996, 1999 and 2010 respectively (Astuti et al., 2016; Pratiwi, 2009). This happened, especially, upon upwelling when excessed pollutants in the bottom moved up replacing dissolved oxygen in the water surface (Astuti et al., 


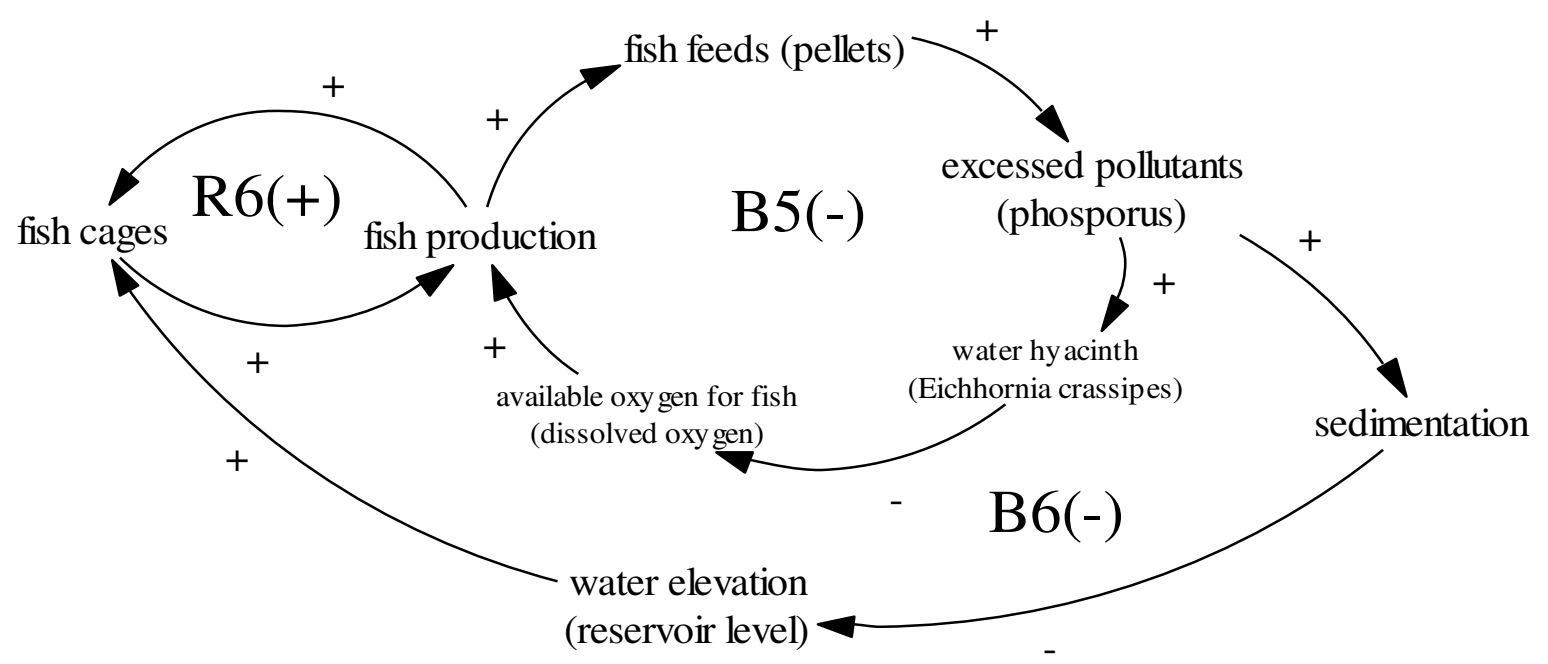

Figure 12. The limits to growth \#2

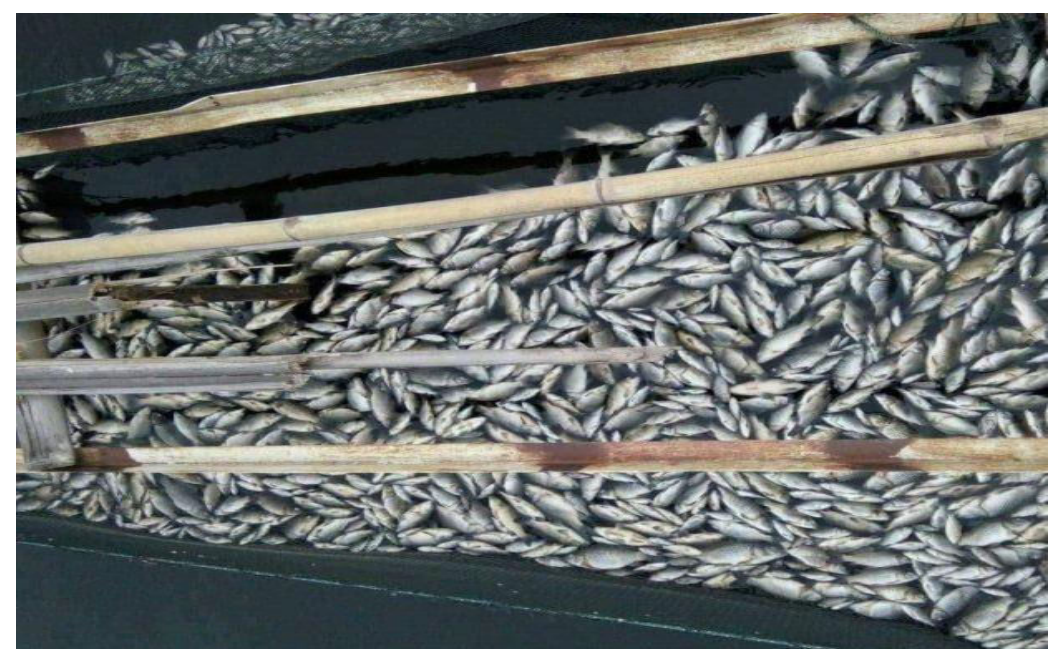

Figure 13. Dead fish owing to overcapacity of fish cages (www.liputan6.com)

Another negative externality of the fish cages is corrosive water turbines (R7) as seen in figure 14. This a reinforcing loop leads to less capability of the reservoir to generate power. Owing to three negative externalities including, massive dead fish, sedimentation, and corrosive water turbines, the local government has banned the new development of fish cages (Deswati, \& Adrison, 2019; Karunia, \& Marinasari, 2015; Koeshendrajana et al., 2011) and has applied a sustainable number of fish cages (Deswati, \& Adrison, 2019; Karunia, \& Marinasari, 2015). 


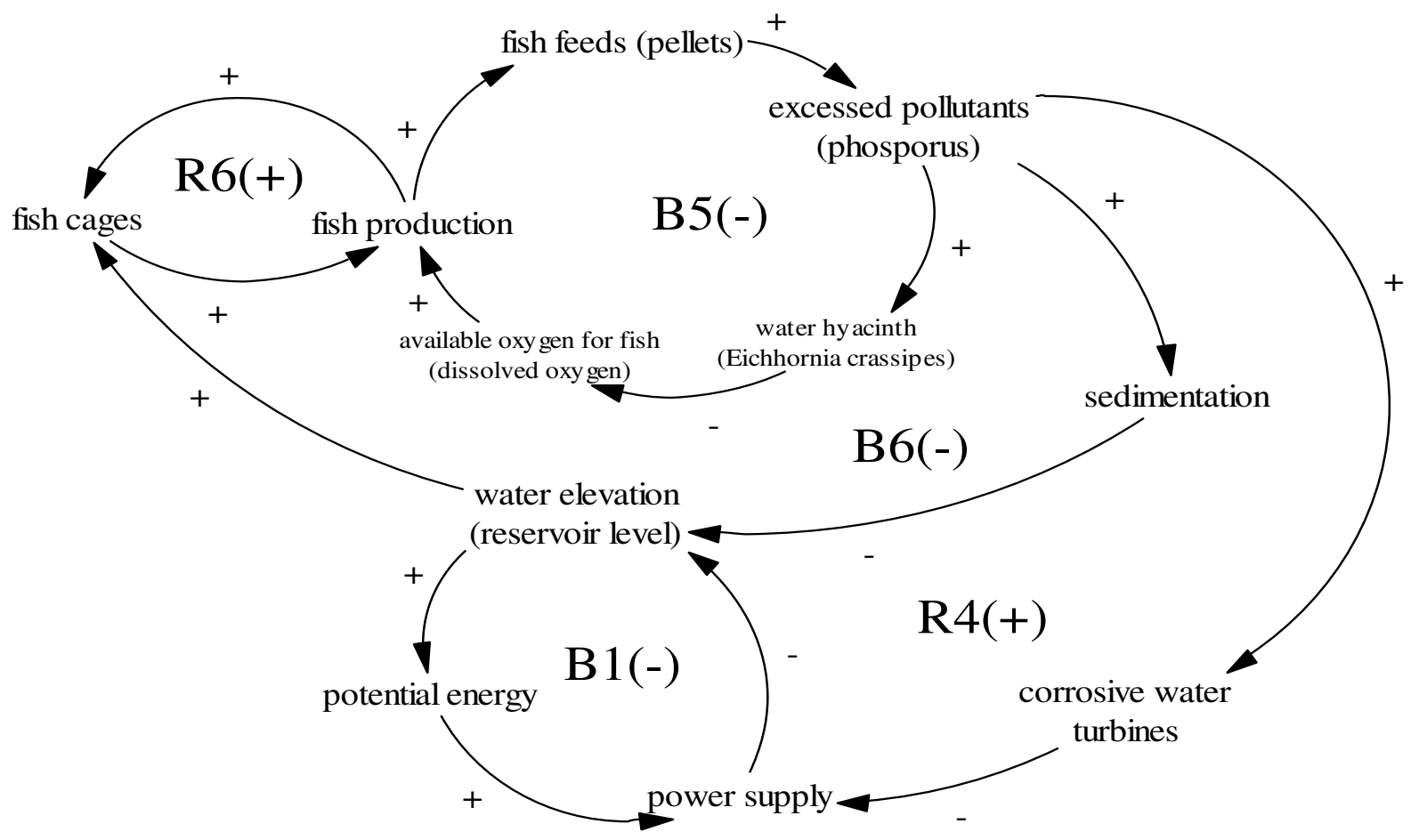

Figure 14. The limits to growth \#2

\subsection{Industry}

The reservoir provides about $5 \%$ of its total water capacity for industrial needs (Slametto, 2012). Please keep in mind that when this study discusses the industrial sector, it means the industrial sectors outside fisheries, especially manufacturing industries such as "Pupuk Kujang Industry" - a large fertilizer manufacture (Effendi, 2009) and industrial parks in West Java (Slametto, 2012). There is a constant outflow from the reservoir to fulfill industrial needs. Landuse change is induced upon the industry development. As expected, the growth engine of industrial development is economic development and it is bounded by water availability as seen in figure 15 . 


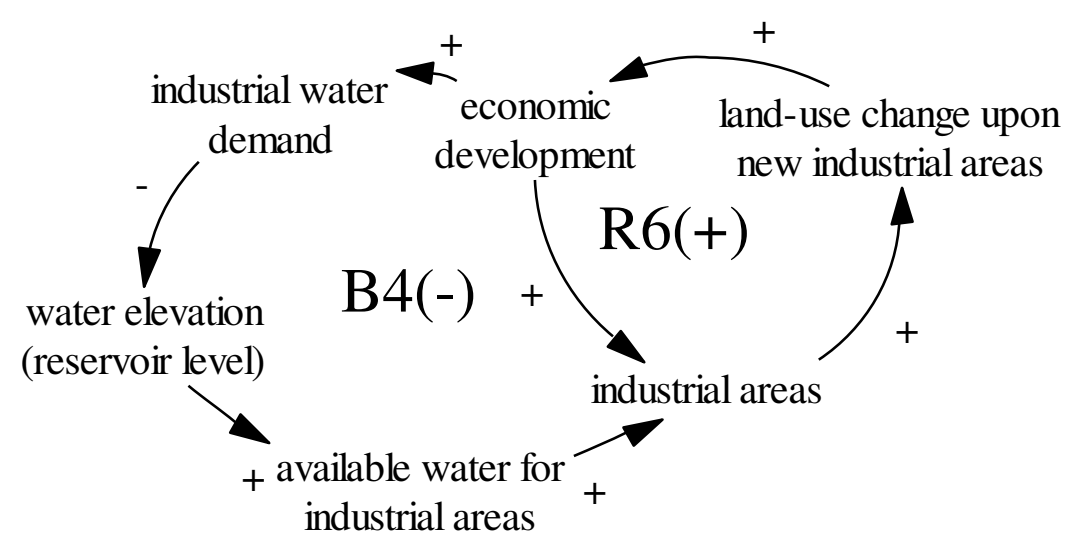

Figure 15. The limits to growth \#3

Another limits to growth in the industrial growth (R6) is limited by limited power supply (B4). Besides water, the reservoir also provides power to the industry sectors in Java and Bali. This means that power availability is another growth engine to support industrial growth. The needs of land and power to support industrial sectors are bounded by limited water and limited power as seen in figure 16. A possible solution is managing the industrial growth, so industrial water demand and industrial power demand increase proportionally to water and power availability in the reservoir.

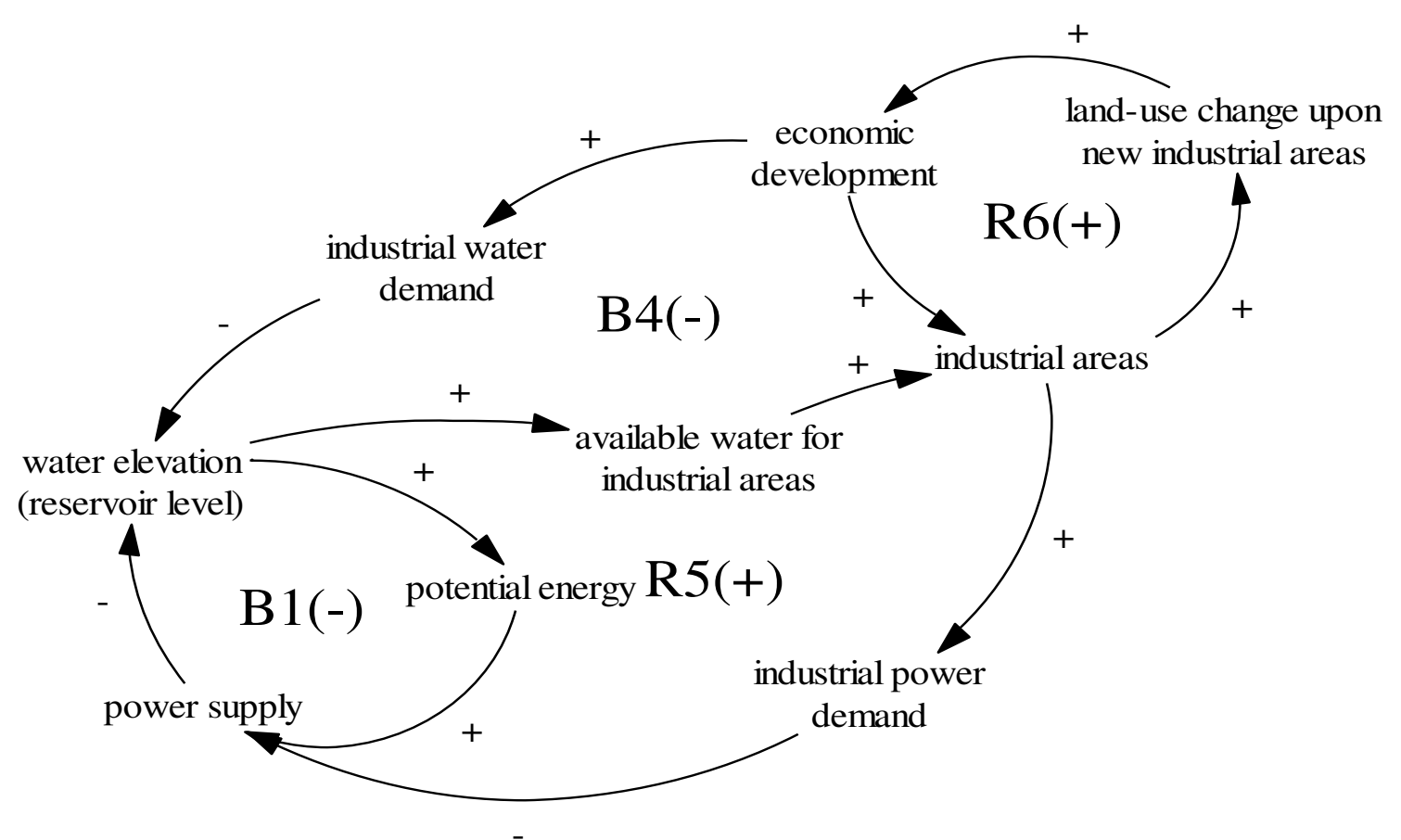

Figure 16. The limits to growth \#3 


\subsection{Residential areas}

The development of residential areas are also supported by water supply. The reservoir provides water for the capital city of Indonesia, Jakarta (e.g. Slametto, 2012). It is about 30\% of total water capacity is distributed to Jakarta (e.g. Slametto, 2012). As seen in figure 17, through land-use change, residential areas are developed (R2). However, again, its residential growth is bounded by water availability as seen in figure 17 ( $\mathrm{R} 2$ and B3). As seen in figure 17, the residential growth is also supported through power supply from the reservoir and, again, it is bounded by power availability (B1 and R3).

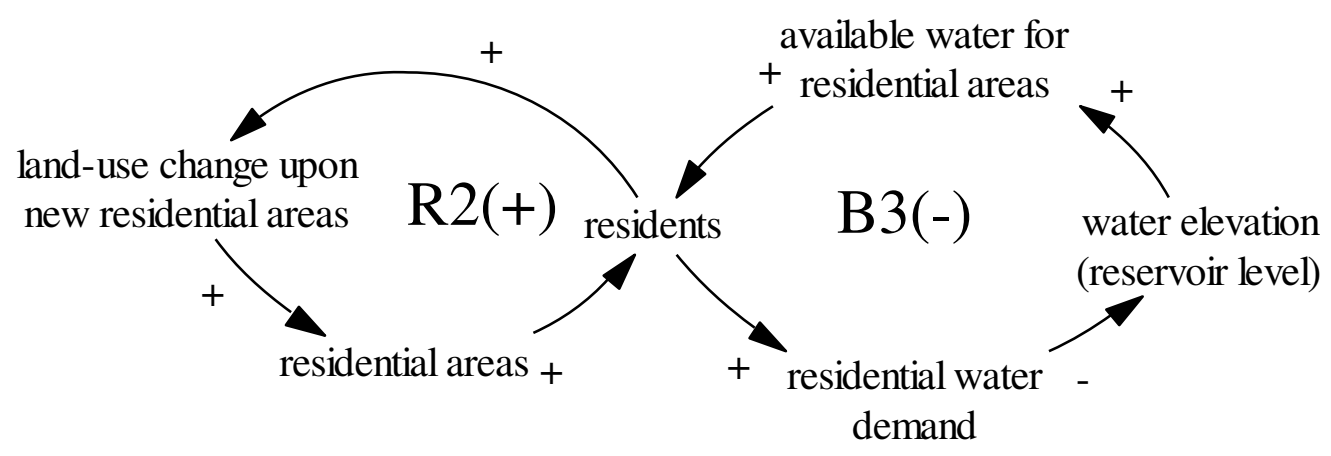

Figure 17. The limits to growth \#4

Similar to the industrial areas, a possible solution is managing the residential growth, so residential water demand and residential power demand increase according to the capacity of the reservoir.

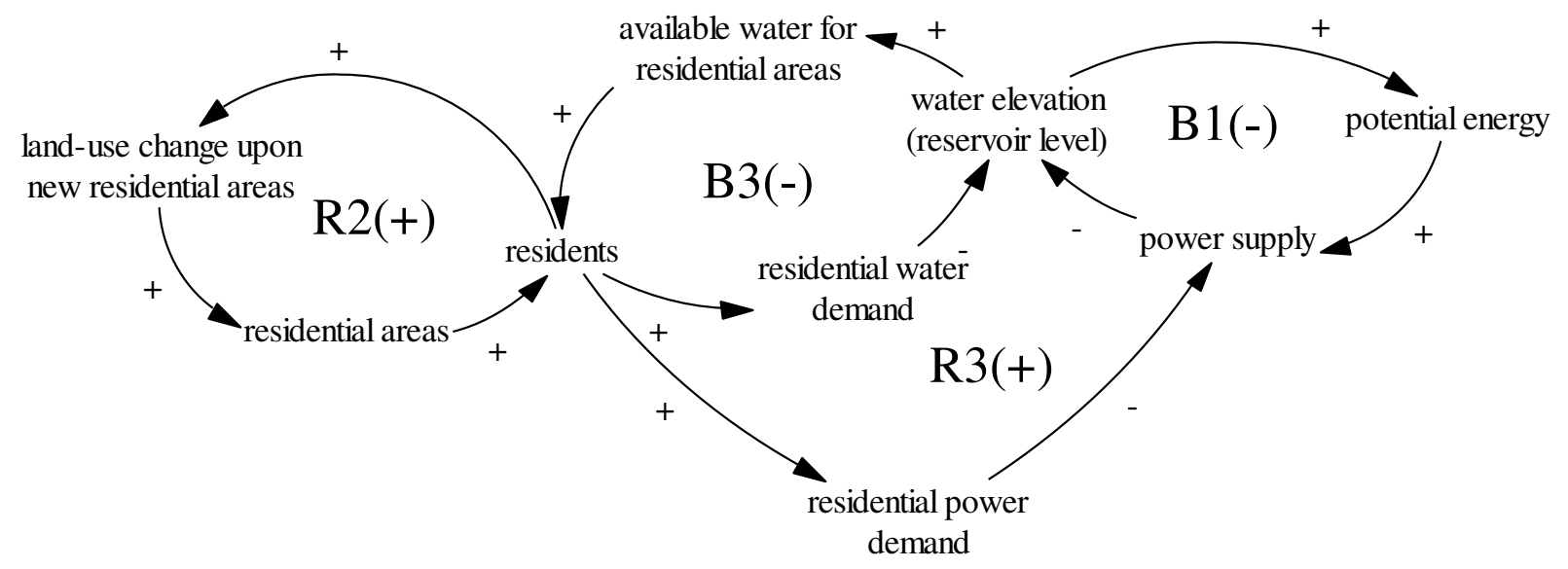

Figure 18. The limits to growth \#4

Another important archetype is the success to successful (R3 and R6). This archetype occurs when two growing activities compete for the same resources. As seen in figure 19, the residential 
growth and the industrial growth competes for the same resource: the power from the reservoir. According to existing studies (Maani \& Cavana, 2007; Senge, 1994), this activity can be resolved through proposed actions such as a policy to share this resource i.e. power supply properly so each growing activity can grow properly.

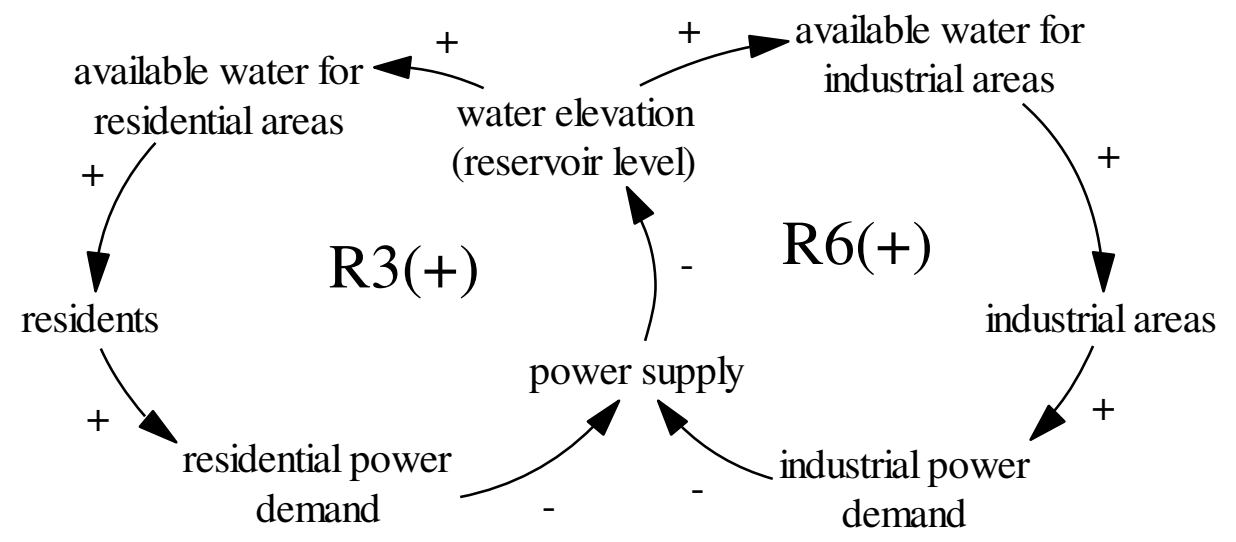

Figure 19. The success to successful \#1

\section{Concluding comments}

As expected, the growth that based on resources such as water and land is bounded by resource availability. This phenomenon is called the limits to growth. As seen in this study and other studies (Banson et al., 2016; Brzezina et al., 2017; Nguyen, \& Bosch, 2013), the limits to growth is a common pattern in the observed systems. The limits to growth recalls our perspectives to be aware of limited resources and interlinked competing agents. In most cases, water security is a common resource that is competed by multiple actors. This is why water security is called the gossamer of the nexus (Matthew, 2018).

Water security owing to an increase in economic growth and population has been a primary consideration across the world as a constraint to the sustainable development (Giampietro, Aspinall, \& Ramos-Martin, 2014; Swatuk \& Cash, 2018). Sustainable solutions to the challenge of environmental changes such as water management and land-use change require our greater understanding of the linkages and dependencies of the nexus elements. The need to address the connection of nexus elements in the Jatiluhur is encouraged as multiple agents and multiple functions exist in the reservoir. Since nexus aims to recognize the interdependencies of the nexus elements such as water and energy, nexus tends to recognize social, economic and environmental consequences.

This study shows that neglecting one nexus elements such as energy would lead to less available power for end users. This study also confirms that focusing on only one nexus element such as food i.e. the fish cages would lead to unsustainable conditions such as massive dead fish 
and corrosive water turbines. With keep this point in mind, focusing on only one nexus element i.e. the fish cages (food production) would lead to greater consequences such as less economic growth, environmental degradation, and social consequences such as unemployment.

As seen in a case of the fish cages, nexus also helps us to increase system efficiency (rather than one-isolated element efficiency), and enhances cooperation among these elements. Because the nexus tends to identify trade-offs, conflicting interests, and possible unintended consequences, the nexus can be a starting point to achieve sustainable development (Giampietro et al., 2014).

Mutiple stakeholders frequently neglect the interconnections of nexus elements. This should be avoided as pressures on one nexus element will induce pressures on other nexus elements. For example, distributing water for irrigation areas and urban areas will minimize a potential energy to produce electricity in the Jatiluhur reservoir. Prioritizing urban areas upon irrigation areas also can increase pressures on water sharing among stakeholders. Which in turn, it can increase pressures on sharing resources among different end users.

The core of the nexus implementation is natural resource availability and the interlinked connection of water, energy and other resources where resource demand and availability are interdependent (e.g. Giampietro et al., 2014). Hence, nexus means a link or a connection of dependent elements. In other words, it is impossible to discuss one element only since each element in the nexus is dynamically dependent to other nexus elements (e.g. Giampietro et al., 2014). 


\section{References}

ADB. (2012). Institutional Strengthening for Integrated Water Resources Management in the 6 Cis River Basin Territory. Decision Support Systems for Integrated Water Resources Management in The Citarum River Basin". Accessed on August 5 ${ }^{\text {th }}, 2019$ at https://www.adb.org/sites/default/files/project-document/75681/37049-023-ino-tacr-01.pdf

Ashuri, A. (2013). Simulasi Komputer Pengaruh Relokasi Keramba Jaring Apung Terhadap Kandungan Nitrat di dalam Air Waduk Jatiluhur. Jurnal Teknik Lingkungan, 19(2), 112-129.

Astuti, L, P., et al. (2016). Tata kelola perikanan berkelanjutan di waduk Jatiluhur. Deepublish

Bahri, M., Cremades, R., Cobian, I., Broekman, A., Pascual, D., Sanchez, A., Ferrer, E., (2018). Deliverable 3.3 : Integrated model with ad-hoc systemic model of urban water supply. Climate Service Center - Germany. Hamburg, Germany.

BPS JABAR.(2018). Jawa Barat dalam angka 2018. Mataram: BPS Propinsi Jawa Barat.

Braun, W. (2002). The system archetypes. System, 2002, 27.

Brouwer, F., Avgerinopoulos, G., Fazekas, D., Laspidou, C., Mercure, J. F., Pollitt, H., \& Howells, M. (2018). Energy modelling and the Nexus concept. Energy Strategy Reviews, 19, 1-6.

BPS Jabar. (2018). Jawa Barat Dalam Angka Tahun 2018. Bandung: Badan Pusat Statistik.

Castaño, S., Murillo, J. M., \& Rodríguez, L. (2001). Alternatives in water resources management in Marina Baja district (Alicante province, Spain). Instituto Geológico y Minero, Madrid.

Cavana, R. Y., \& Ford, A. (2004). Environmental and resource systems: Editors' introduction. System Dynamics Review, 20(2), 89-98.

Chhipi-Shrestha, G., Hewage, K., \& Sadiq, R. (2017). Water-energy-carbon nexus modeling for urban water systems: System dynamics approach. Journal of Water Resources Planning and Management, 143(6), 04017016.

Deswati, R. H., \& Adrison, V. (2019). Eksternalitas produksi keramba jaring apung waduk jatiluhur. Jurnal Ilmu Ekonomi dan Pembangunan, 19(1), 49-62.

Duran-Encalada, J. A., Paucar-Caceres, A., Bandala, E. R., \& Wright, G. H. (2017). The impact of global climate change on water quantity and quality: A system dynamics approach to the USMexican transborder region. European Journal of Operational Research, 256(2), 567-581.

Effendi, A. (2009). Prof. Dr. Ir. Sedyatmo: Intuisi mencetus daya cipta. Mizan. Jakarta. 
Ferroukhi, R., Nagpal, D., Lopez-Peña, A., Hodges, T., Mohtar, R. H., Daher, B., ... \& Keulertz, M. (2015). Renewable energy in the water, energy \& food nexus. IRENA, Abu Dhabi.

Fitri, N. (2016). Analisis daya dukung dan kelembagaan usaha keramba jaring apung (KJA) di waduk Jatiluhur. Unpublished thesis. Institut Pertanian Bogor, Bogor, Indonesia

Ford, A. (1999). Modeling the environment: An introduction to system dynamics models of environmental systems. Island press.

Giampietro, M., Aspinall, R. J., \& Ramos-Martin, J. (2014). Addressing the complexity of integrated resource assessment. In Resource Accounting for Sustainability Assessment (pp. 2330). Routledge.

Gohari, A., Madani, K., Mirchi, A., \& Bavani, A. M. (2014). System-Dynamics approach to evaluate climate change adaptation strategies for Iran's Zayandeh-Rud Water System. In World Environmental and Water Resources Congress 2014(pp. 1598-1607).

Hamzah, H. (2017). Status Mutu Air Waduk Jatiluhur Dan Ancaman Terhadap Proses Bisnis Vital. Jurnal Sumber Daya Air, 12(1), 47-60.

Hasan, M. (2011). Model Kebijakan Pengelolaan Sumber Daya air pada daerah aliran (DAS) Citarum yang berkelanjutan. Unpublished thesis. Institut Pertanian Bogor, Bogor, Indonesia

Hardjamulia, A., Setiadi, K. E., \& Rabegnatar, W. S. (1988). Some biological aspects of the predominant fish species in the Jatiluhur Reservoir, West Java, Indonesia. In Reservoir fishery management and development in Asia: proceedings of a workshop held in Kathmandu, Nepal, 23-28 Nov. 1987. IDRC, Ottawa, ON, CA.

Kajisa, T., \& Dhalhar, A. (1998). Application of the sedimentation model to Jatiluhur and Anon dam reservoirs. Rural and Environment Engineering, 1998(35), 27-34.

Kartamihardja, E. S. (2017). Perubahan Komposisi Komunitas Ikan Dan Faktor-Faktor Penting Yang Memengaruhi Selama Empat Puluh Tahun Umur Waduk Djuanda [Change of Fish Community Composition and The Influencing Important Factors During Fourty Years of The Djuanda Reservoir Impounded]. Jurnal Iktiologi Indonesia, 8(2), 67-78.

Kartamihardja, E. S., \& Umar, C. (2006). Culture, capture conflicts: sustaining fish production and livelihoods in Indonesian reservoirs. Capture Fisheries Component, ACIAR-DGA Indonesia, Final Report.

Karunia, S., \& Marinasari, R. (2015). Analisis Biaya Eksternalitas Limbah Pakan Usaha Keramba Jaring Apung di Waduk Jatiluhur Kabupaten Purwakarta. Buletin Ilmiah Marina Sosial Ekonomi Kelautan dan Perikanan, 1(2), 77-88. 
Katiandhago, T,M,. (2007). Model pengelolaan sumber daya air dalam kompetisi antar sektor di wilayah hilir daerah irigasi jatiluhur: Pendekatan optimasi dinamik. Unpublished thesis. Institut Pertanian Bogor, Bogor, Indonesia

Kim, D. H. (1992). System archetypes at a glance. System. Thinker, 3(5).

Koeshendrajana, S., Apriliani, T., Firdaus, M., Nasution, Z., \& Nurfiarini, A. (2011). Penebaran ikan bandeng di Waduk Jatiluhur: analisis dampak dan kebijakan pengembangan. Jurnal Kebijakan Sosial Ekonomi Kelautan dan Perikanan, 1(1), 1-17.

Maani.K. \& Cavana.R.Y. (2007). Introduction to system thinking. Auckland, New Zealand: Pearson Education New Zealand

Madani, K., \& Mariño, M. A. (2009). System dynamics analysis for managing Iran's ZayandehRud river basin. Water resources management, 23(11), 2163-2187.

Madani, K., \& Mariño, M. A. (2009). System dynamics analysis for managing Iran's ZayandehRud river basin. Water resources management, 23(11), 2163-2187.

Martínez-Ibarra, E. (2015). Climate, water and tourism: causes and effects of droughts associated with urban development and tourism in Benidorm (Spain). International Journal of Biometeorology, 59(5), 487-501.

Matthew, R. A. (2018). Afterward: Closing Thoughts on the Water-Food-Energy-Climate Nexus. In Water, Energy, Food and People Across the Global South (pp. 325-332). Palgrave Macmillan, Cham.

Mirchi, A., \& Watkins Jr, D. (2012). A systems approach to holistic total maximum daily load policy: case of Lake Allegan, Michigan. Journal of Water Resources Planning and Management, 139(5), 544-553.

Nasution, Z. (2005). Institutional Analysis on Managing of Reservoir Environment (a Case Study at Jatiluhur Reservoir-West Java). Buletin Ekonomi Perikanan, 6(1).

Nguyen, N. C., \& Bosch, O. J. (2013). A systems thinking approach to identify leverage points for sustainability: a case study in the Cat Ba Biosphere Reserve, Vietnam. Systems Research and Behavioral Science, 30(2), 104-115

Pratiwi, A. (2009). Pengaruh Pencampuran Massa Air terhadap Ketersediaan Oksigen Terlarut pada Lokasi Keramba Jaring Apung di Waduk Ir. H. Juanda, Purwakarta. Unpublished thesis. Institut Pertanian Bogor, Bogor, Indonesia

Pratiwi, P. I. (2010). Perencanaan penataan lanskap kawasan wisata dan penyusunan alternatif program Wisata di Grama Tirta Jatiluhur, Kabupaten Purwakarta, Provinsi Jawa Barat. Unpublished thesis. Institut Pertanian Bogor, Bogor, Indonesia 
Priyatna, N, F., (2013). Kontestasi kepentingan dalam pengelolaan sumber daya perairan Waduk Djuanda, Jatiluhur. Unpublished thesis. Institut Pertanian Bogor, Bogor, Indonesia

Purnamaningtyas, S. E., \& Tjahjo, D. W. (2017). Beberapa aspek biologi ikan oskar (amphilophus citrinellus) di waduk Ir. H. Djuanda, Jatiluhur, Jawa Barat. Widya Riset Perikanan Tangkap, 3(1), 9-16.

Rico-Amoros, A. M., Saurí, D., Olcina-Cantos, J., \& Vera-Rebollo, J. F. (2013). Beyond megaprojects?. Water alternatives for mass tourism in coastal Mediterranean Spain. Water Resources Management, 27(2), 553-565.

Ridwan, A. (2014).Analisis perbandingan tingkat pendapatan dan faktor yang mempengaruhi pilihan sistem budidaya ikan dalam keramba jaring apung (Studi Kasus Waduk Jatiluhur Kabupaten Purwakarta). Unpublished thesis. Institut Pertanian Bogor, Bogor, Indonesia

Samekto, C., \& Winata, E. S. (2010). Potensi sumber daya air di Indonesia. In Seminar Aplikasi Teknologi Penyediaan Air Bersih untuk Kabupaten/Kota di Indonesia. Pusat Teknologi Lingkungan. BPPT.

Santana Aji, H, G. (2014). Evaluasi laju sedimentasi pada waduk jatiluhur, kabupaten Purwakarta, Jawa Barat. Unpublished thesis. Institut Pertanian Bogor, Bogor, Indonesia

Senge, P. M. (1991). The fifth discipline, the art and practice of the learning organization. Performance+ Instruction, 30(5), 37-37.

Senge, P. M. (2014). The fifth discipline fieldbook: Strategies and tools for building a learning organization. Crown Business.

Slametto. (2012). Analisis ekonomi dan hidrologi pengelolaan sumberdaya air waduk juanda oleh perusahaan umum jasa tirta ii: pendekatan optimasi dinamik. Unpublished thesis. Institut Pertanian Bogor, Bogor, Indonesia

Sofia, Y. (2013). Emisi Gas Metana Dari Waduk Saguling, Cirata Dan Jatiluhur. Jurnal Sumber Daya Air, 9(2), 131-142.

Sohofi, S. A., Melkonyan, A., Karl, C., \& Krumme, K. (2016). System archetypes in the conceptualization phase of water-energy-food nexus modeling. In double peer-reviewed conference proceedings of the 34th International Conference of the System Dynamics Society, Delft, Netherlands, July (pp. 17-21).

Sterman, J.D. (2001). Business dynamics: Systems thinking and modeling for a complex world. Boston, MA:Irwin McGraw Hill.

Tukayo, R, K. (2011). Perubahan penggunaan lahan das citarum dan dampaknya terhadap suplai air irigasi. Unpublished thesis. Institut Pertanian Bogor, Bogor, Indonesia 
Wolstenholme, E. (2004). Using generic system archetypes to support thinking and modelling. System Dynamics Review: The Journal of the System Dynamics Society, 20(4), 341-356.

Yoshida, K., Azechi, I., Hariya, R., Tanaka, K., Noda, K., Oki, K., ... \& Shirakawa, H. (2013). Future Water Availability in the Asian Monsoon Region: A case study in Indonesia. Journal of Developments in Sustainable Agriculture, 8(1), 25-31. 